\title{
Arugula production as a function of irrigation depths and potassium fertilization
}

\author{
Elis M. de Freitas ${ }^{1}$, Luan B. Giovanelli², Fábio T. Delazari ${ }^{3}$, \\ Márcio L. dos Santos ${ }^{3}$, Silvio B. Pereira ${ }^{2} \&$ Derly J. H. da Silva ${ }^{3}$ \\ ${ }^{1}$ Universidade Federal dos Vales do Jequitinhonha e Mucuri/Centro de Ciências Agrárias/Departamento de Agronomia. Viçosa, MG. E-mail: \\ elis_stavanato@hotmail.com \\ ${ }^{2}$ Universidade Federal de Viçosa/Centro de Ciências Agrárias/Departamento de Engenharia Agrícola. Viçosa, MG. E-mail: luan.giovanelli@ufv.br; \\ silviopereira.ufv@gmail.com \\ ${ }^{3}$ Universidade Federal de Viçosa/Centro de Ciências Agrárias/Departamento de Fitotecnia. Viçosa, MG. E-mail: fabio.delazari@ufv.br (Corresponding \\ author); marcio.luizufv@gmail.com; derly@ufv.br
}

\section{Key words:}

Eruca sativa L.

drip tape

plant nutrition

\begin{abstract}
A B S T R A C T
Arugula is a vegetable that has gained more highlight in the consumption, being rich in potassium, sulfur, iron, omega-3 and vitamins A and C. Availability of water and nutrients are limiting factors for production of this crop. In this context, the objective of this study was to evaluate the production of arugula subjected to different irrigation depths and potassium fertilization. The experiment was conduct between August and September 2015. The experimental design was completely randomized in split-plot scheme. Irrigation depths $\mathrm{L}_{1}, \mathrm{~L}_{2}, \mathrm{~L}_{3}$ and $\mathrm{L}_{4}(25,50,75$ and $100 \%$ of crop evapotranspiration, respectively) represented the plots and potassium doses $\mathrm{K}_{1}$ and $\mathrm{K}_{2}$ (200 and $400 \mathrm{~kg} \mathrm{ha}^{-1}$, respectively) represented the subplots. Although the highest yield was obtained with highest irrigation depth and highest potassium dose, it is recommended the cultivation of arugula with the lowest irrigation depth and the lowest potassium dose, considering the higher value of water use efficiency for this treatment.
\end{abstract}

\section{Palavras-chave: Eruca sativa L. fita gotejadora nutrição de plantas}

\section{Produção da rúcula em função da lâmina de irrigação e da adubação potássica}

\begin{abstract}
R E S U M O
A rúcula é uma hortaliça que tem ganhado cada vez mais destaque na alimentação, sendo rica em potássio, enxofre, ferro, ômega-3 e vitaminas A e C. É uma cultura que possui, como fatores limitantes para sua produção, a disponibilidade de água e de nutrientes, contexto no qual se objetivou, neste trabalho, avaliar a produção da rúcula submetida a diferentes lâminas de irrigação e doses de adubação potássica. O experimento foi conduzido entre agosto e setembro de 2015. O delineamento experimental utilizado foi o inteiramente casualizado, no esquema de parcelas subdivididas. As parcelas foram representadas pelas lâminas de irrigação $\mathrm{L}_{1}, \mathrm{~L}_{2}, \mathrm{~L}_{3}$ e $\mathrm{L}_{4}(25,50,75$ e $100 \%$ da evapotranspiração da cultura, respectivamente), e as subparcelas pelas doses de potássio $\mathrm{K}_{1}$ e $\mathrm{K}_{2}$ (200 e $400 \mathrm{~kg} \mathrm{ha}^{-1}$, respectivamente). Embora a maior produtividade tenha sido obtida com a maior lâmina de irrigação e maior dose de potássio, recomenda-se o cultivo da rúcula com a menor lâmina e menor dose, haja vista o maior valor de eficiência do uso da água para este tratamento.
\end{abstract}




\section{INTRODUCTION}

Arugula (Eruca sativa L.), also called rocket salad, is an herbaceous vegetable from the Brassicaeae family (Borges et al., 2014). It has small size and reaches height of 15 to $20 \mathrm{~cm}$ at the point of harvest, with elongated leaves with deeply cut blades, dark green color and spicy taste, rich in potassium, sulfur, iron and vitamins A and C (Gonzalez et al., 2006).

According to Carvalho et al. (2012), arugula has gained more and more space on the table of the Brazilian population and prominence in the market, because of its nutritional composition. Still according to these authors, it is a crop highly sensitive to water deficit and irrigation is a very important practice for its good development and better yield.

Another relevant factor in arugula production is its nutrition. It is known that the adequate supply of nutrients from the stage of plantlet until harvest favors the success of the production of any vegetable. For arugula, any nutritional imbalance can be irreversible due to the short growth period (Cecílio Filho et al., 2014).

In this context and in relation to the availability of nutrients, potassium has become important because, according to Silveira et al. (2015), it participates in the synthesis of sugars and proteins in the process of photosynthesis to obtain energy, in the translocation of carbohydrates and proteins and in water absorption.

Considering the importance of the arugula crop and the absence of information on its water-nutritional requirement, the present study aimed to evaluate the production of arugula subjected to different irrigation depths and potassium fertilization doses.

\section{Material AND Methods}

The experiment was conducted at the Research Vegetable Garden of the Federal University of Viçosa (UFV), in Viçosa, MG, situated at $20^{\circ} 45^{\prime} 14^{\prime \prime} \mathrm{S}, 42^{\circ} 52^{\prime} 53^{\prime \prime} \mathrm{W}$ and altitude of $648 \mathrm{~m}$, between August and September 2015.

After physical analysis of the soil in the experimental area, it was classified as sandy clay loam (Lemos \& Santos, 2005),

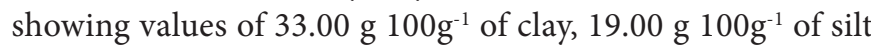

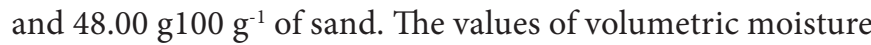
at field capacity and permanent wilting point were 0.36 and $0.22 \mathrm{~m}^{3} \mathrm{~m}^{-3}$, respectively. The chemical analysis exhibited the following characteristics of the soil: $\mathrm{pH}$ : 6.3, using a $\mathrm{pH}$ meter; base saturation (V): $52 \%$; mean content of organic matter, determined by the Walkley-Black method: 3.1 dag $\mathrm{kg}^{-1}$; available contents of $\mathrm{P}$ and $\mathrm{K}$, extracted with Mehlich I: 24.6 and $120.0 \mathrm{mg} \mathrm{dm}^{-3}$, respectively; exchangeable contents of $\mathrm{Ca}^{2+}$ and $\mathrm{Mg}^{2+}$, extracted with $1.0 \mathrm{~mol} \mathrm{~L}^{-1} \mathrm{KCl}: 3.1$ and 0.8 cmol $\mathrm{dm}^{-3}$, respectively; potential acidity $(\mathrm{H}+\mathrm{Al})$, extracted with $1.0 \mathrm{~mol} \mathrm{~L}^{-1}$ calcium acetate at $\mathrm{pH} 7.0 ; 4.0 \mathrm{cmol} \mathrm{dm}_{c}^{-3}$ and $\mathrm{CEC}$ at $\mathrm{pH}$ 7.0, determined through the sum of $\mathrm{Ca}^{2+}+\mathrm{Mg}^{2+}+$ $\mathrm{K}^{+}+(\mathrm{H}+\mathrm{Al}): 8.2 \mathrm{cmol} \mathrm{dm}^{-3}$.

The experimental design was completely randomized (CRD) in split-plot scheme, with five replicates, and each replicate consisted of three plants. Plots were represented by the irrigation depths $\mathrm{L}_{1}, \mathrm{~L}_{2}, \mathrm{~L}_{3}$ and $\mathrm{L}_{4}$, referring to 25,50 , 75 and $100 \%$ of crop evapotranspiration (ETc), respectively.
The subplots contained the treatments corresponding to the potassium doses $\mathrm{K}_{1}$ and $\mathrm{K}_{2}$, referring to 200 and $400 \mathrm{~kg} \mathrm{ha}^{-1}$ of $\mathrm{K}_{2} \mathrm{O}$, respectively. The dose $\mathrm{K}_{2}$ was adopted according to the recommendation of Porto et al. (2013), in a study that points out the maximum water use efficiency by arugula when subjected to this dose, while the dose $\mathrm{K}_{1}$ was adopted by the authors to study the behavior of arugula in a nutritional condition below the recommended one.

Sowing was performed on August 21, 2015, on trays with 200 cells and the substrate for plants 'Carolina, Padrão II', EC $=1.5 \mathrm{mS} \mathrm{cm}^{-1} \pm 0.3$, using three seeds per cell of the cultivar 'Astro'. Transplanting occurred on September 2, when the seedlings reached the first pair of true leaves. 400 seedlings were transplanted at spacing of $0.10 \times 0.20 \mathrm{~m}$ and arranged in 4 beds ( $1 \mathrm{~m}$ wide $\mathrm{x} 2 \mathrm{~m}$ long). Each bed received one irrigation depth and the potassium doses. The experimental plots had total area of $0.7 \mathrm{~m}^{2}$, evaluation area of $0.3 \mathrm{~m}^{2}$ and were separated by $30 \mathrm{~cm}$. Arugula plants were harvested on September 28 .

A drip tape was used, operating with flow rate of $1.72 \mathrm{~L}$ $\mathrm{h}^{-1}$, at pressure of $10.0 \mathrm{mwc}$, and Christiansen Uniformity Coefficient (CUC) of $98.7 \%$. The drippers on the tape were spaced by $0.30 \mathrm{~m}$. On the beds, the tapes were spaced by 0.40 $\mathrm{m}$, resulting in an application intensity of $14.35 \mathrm{~mm} \mathrm{~h}^{-1}$.

Irrigation frequency of two to three days was used in the management of irrigation depth, with water demand calculated by the estimate of crop evapotranspiration (ETc), constituting the treatments. Eqs. 1 and 2 were used to estimate crop evapotranspiration (Allen et al., 2006; Angeli et al., 2016).

$$
\mathrm{ETc}=\mathrm{ETo} \times \mathrm{Kc}
$$

$$
\mathrm{Kc}=(\mathrm{Kcb} \times \mathrm{Ks})+\mathrm{Ke}
$$

where:

ETc - crop evapotranspiration, $\mathrm{mm} \mathrm{d}^{-1}$;

ETo - reference evapotranspiration, $\mathrm{mm} \mathrm{d}^{-1}$;

Kc - crop coefficient;

Kcb - basal crop coefficient;

Ke - soil evaporation coefficient; and,

Ks - stress coefficient.

The arugula cycle was divided into phenological stages based on the growth period or vegetative period, related to the shading of the area, in which each stage assumed a different value of crop coefficient (Kc). The calculations used coriander $\mathrm{Kcb}$ values, because of the lack of information on arugula. The initial, intermediate and final $\mathrm{Kcb}$ values were $0.15,1.10$ and 0.70, respectively (Silva et al., 2013).

Along the experiment, the irrigation depths applied in the treatments referring to 25,50, 75 and $100 \%$ of crop evapotranspiration (ETc) were 19.7, 39.5, 59.2 and $79.0 \mathrm{~mm}$, respectively.

The daily data of maximum, mean and minimum temperature $\left({ }^{\circ} \mathrm{C}\right)$ and relative air humidity $(\%)$, solar radiation

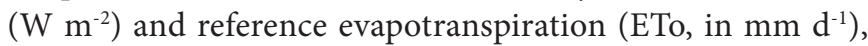
used for irrigation management are presented in Figure 1. These data were obtained using a meteorological station installed in the experimental area. 
A.

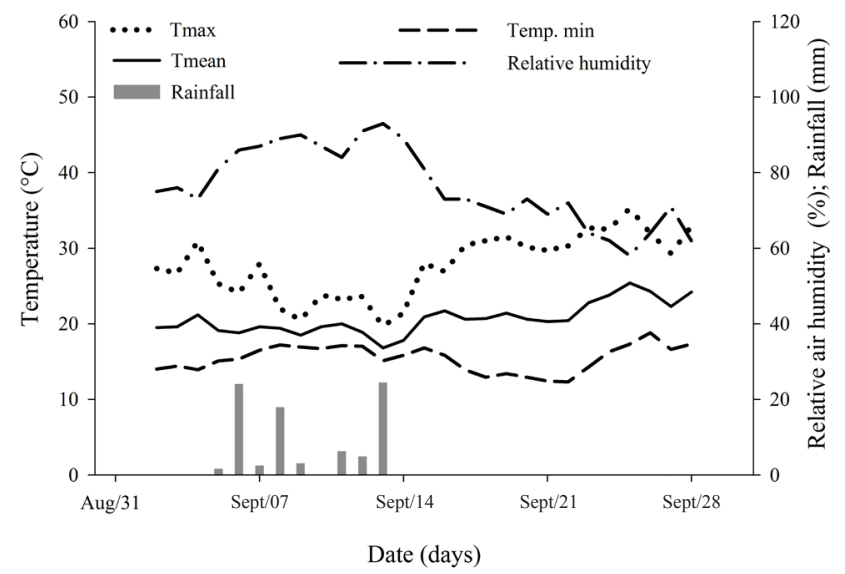

B.

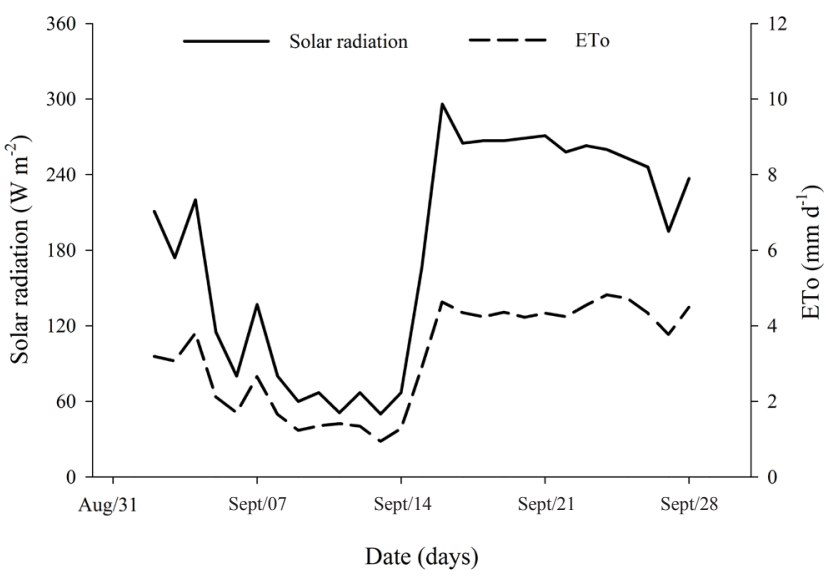

Figure 1. Daily values of maximum, mean and minimum temperature, relative air humidity and rainfall (A) and solar radiation and reference evapotranspiration (B) for the period of arugula cultivation

Soil acidity was not corrected, because the $\mathrm{pH}$ of the soil of the experiment (6.3) was within the ideal range (5.5 to 6.5) recommended to maintain ideal levels of macro and micronutrients for cultivated plants (Ribeiro et al., 1999). At transplanting, the soil received $600 \mathrm{~kg} \mathrm{ha}^{-1}$ of $\mathrm{P}_{2} \mathrm{O}_{5}$ in the form of single superphosphate $\left(18 \% \mathrm{P}_{2} \mathrm{O}_{5}\right)$ and $400 \mathrm{~kg} \mathrm{ha}^{-1}$ of N in the form of ammonia sulfate $(20 \% \mathrm{~N})$. Potassium fertilization was split using $\mathrm{KCl}\left(59 \%\right.$ of $\left.\mathrm{K}_{2} \mathrm{O}\right)$ as source of $\mathrm{K}$. In the treatment $\mathrm{K}_{1}\left(200 \mathrm{~kg} \mathrm{ha}^{-1}\right.$ of $\left.\mathrm{K}_{2} \mathrm{O}\right)$, half of the dose was applied at planting and the other half split into two applications - at 8 and 16 days after transplanting (DAT). For the treatment $\mathrm{K}_{2}\left(400 \mathrm{~kg} \mathrm{ha}^{-1}\right.$ of $\left.\mathrm{K}_{2} \mathrm{O}\right), 42.25 \%$ of the recommended dose was applied at planting and the rest split into two similar applications, at 8 and 16 DAT.

After reaching the commercial size of 20 to $30 \mathrm{~cm}$, the 15 central plants of each treatment were harvested and their heights were measured. After harvest, leaves were passed in the leaf area integrator LAI 3010 (Licor Inc., Lincoln, NE, USA) and the fresh matter was quantified. Water use efficiency (WUE) was also evaluated, defined by the relationship between production and the applied water volume, expressed in $\mathrm{kg} \mathrm{m}^{-3}$. On the day of harvest, leaf temperature was measured with an

A.

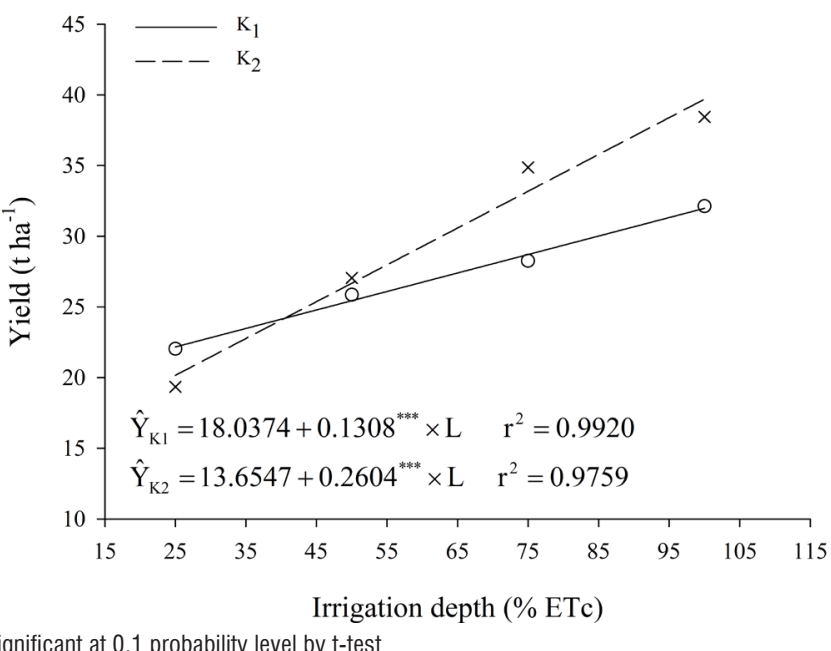

infrared thermometer and chlorophyll index was determined with a ClorofiLog device (Falker, Porto Alegre, RS, Brazil).

The data were analyzed through regression analysis. The equations were fit for each $\mathrm{K}$ dose correlating the irrigation depths with the evaluated characteristics. The regression models were selected based on the significance of the regression coefficients using the $\mathrm{t}$-test at 0.1 probability level.

\section{Results AND Discussion}

The responses of arugula yield and height to the irrigation depths for each $\mathrm{K}$ dose are presented in Figure 2.

It is observed in Figure 2 that the increment of 1\% in ETc promoted a yield increase of $0.1308 \mathrm{tha}^{-1}$ in the treatments that received the dose $\mathrm{K}_{1}$ and $0.2604 \mathrm{tha}^{-1}$ in those that received the dose $\mathrm{K}_{2}$.

The plant responded positively to the increment in $\mathrm{K}$ doses as the irrigation depths increased. For lower irrigation depths (25 and $50 \%$ of ETc), the supply of K little influenced yield. For the irrigation depth of $25 \%$, for instance, twice the $\mathrm{K}$ dose led to lower yield. This behavior can be attributed to the fact that potassium chloride is a salt, which may have increased the

B.

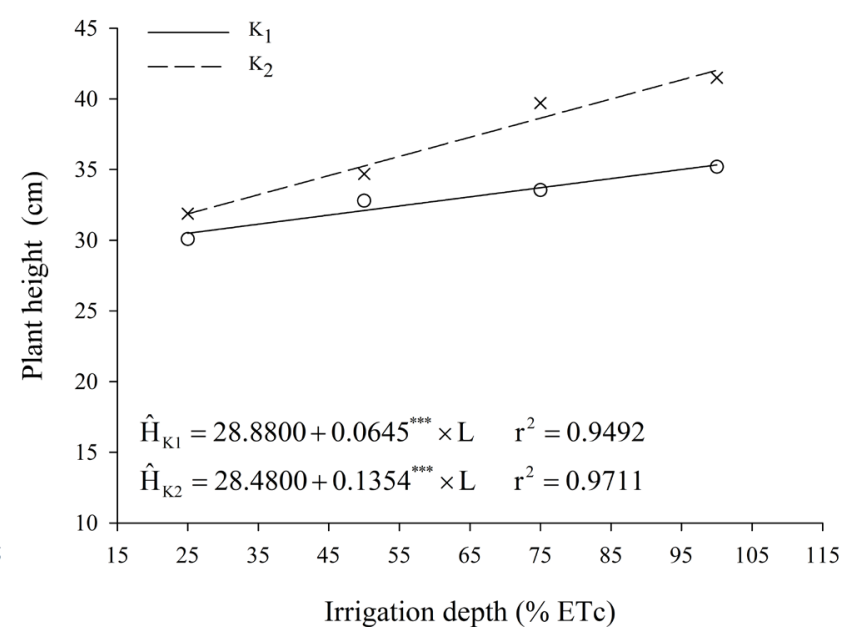

Figure 2. Response of arugula yield (A) and height (B) as a function of the applied irrigation depth (\% ETC) for each potassium dose 
osmotic potential of the soil under low water supply condition, compromising the absorption of water and nutrients by plant roots.

Maximum yield ( $39.7 \mathrm{t} \mathrm{ha}^{-1}$ ) was obtained for the irrigation depth $\mathrm{L}_{4}$ and potassium dose $\mathrm{K}_{2}$. This maximum yield occurred probably because the water contents in the soil were adequate for the crop, which allowed greater absorption of water and nutrients. The water deficit caused by the application of the lowest irrigation depths damaged the development of the plants.

The first and most sensitive response to water deficit is the decrease in turgor and, associated with this event, the reduction of the process of plant growth in extension (Chaves Filho \& Stacciarini-Seraphin, 2001; Larcher, 2006). Under water deficit condition, there is a restriction to biomass accumulation, which damages the number of leaves both in the initial and later stages, limiting the dimension of individual leaves and, consequently, total leaf area, number and growth rates of branches and stem growth (Osório et al., 1998).

Another hypothesis that may have contributed to the increment in yield as $\mathrm{K}$ doses and irrigation depths increased is the relationship between $\mathrm{K}$ and $\mathrm{N}$, the water supply and the dynamics of $\mathrm{K}^{+}$in the soil. $\mathrm{K}$ can act in the better use of other nutrients in the plant, such as $\mathrm{N}$, which was observed in the treatments that received the highest irrigation depths. With greater K availability, there is a better assimilation of N, which acts in the increase of photosynthetic activity due to the higher chlorophyll indices. Hence, the use of $\mathrm{N}$ allows the increase in its absorption, assimilation and nutrition and, consequently, in plant yield (Viana \& Kiehl, 2010).

According to Figure 2B, the variable plant height followed a behavior similar to that of yield. As the irrigation depth increased for both $\mathrm{K}$ doses, plant height increased. The highest $\mathrm{K}$ dose $\left(\mathrm{K}_{2}\right)$, associated with the highest irrigation depth $\left(\mathrm{L}_{4}\right)$, resulted in the highest value of plant height $(42 \mathrm{~cm})$.

The increment of $1 \%$ in ETc caused an increase of 0.0645 $\mathrm{cm}$ in plant height in the treatment $\mathrm{K}_{1}$ and $0.1354 \mathrm{~cm}$ in the treatment $\mathrm{K}_{2}$, being almost two times higher in the treatment with the highest $\mathrm{K}$ dose.

A.

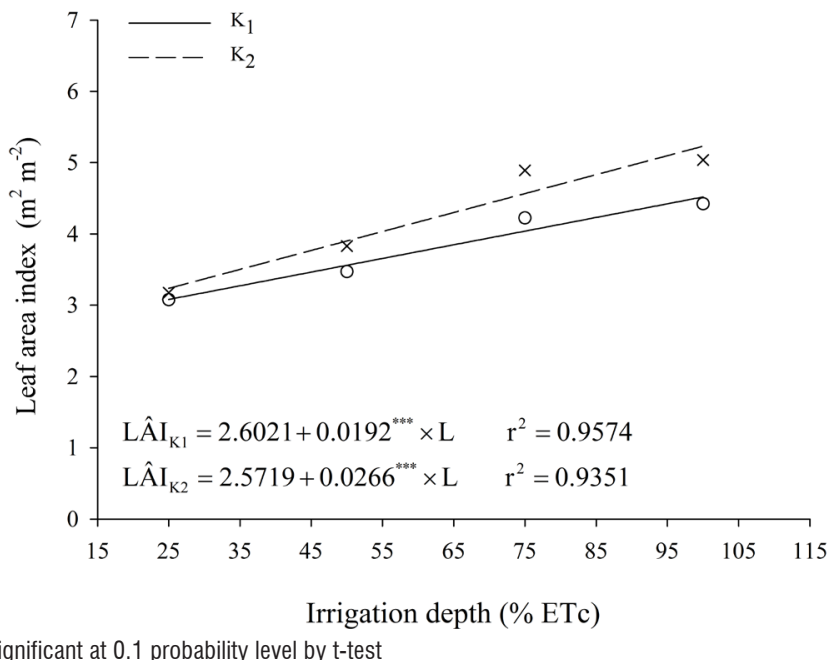

$\mathrm{K}$ is an essential macronutrient for higher plants and the third element that most limits plant growth, with important role in the translocation of compounds elaborated in the plant tissue (Marenco \& Lopes, 2005). It is appropriate to point out that leafy vegetables deserve attention with respect to water use, because the plants are strictly sensitive to water regime and the lack of water can compromise plant growth, while its excess can damage root respiration and lead to the occurrence of diseases.

The responses of the variables leaf area index and chlorophyll as a function of the irrigation depths for each $\mathrm{K}$ dose are presented in the figure below.

According to Figure 3, when the irrigation depth $\mathrm{L}_{1}$ was applied, in comparison to $\mathrm{L}_{4}$, for both $\mathrm{K}$ doses, there was an increment in leaf area index. The greater supply of $\mathrm{K}$ promoted an increase in the variation of leaf area index from 0.0192 to $0.0266 \mathrm{~m}^{2} \mathrm{~m}^{-2}$ for each 0.01 increase in the ETc applied in the treatments.

The highest value of leaf area index $\left(5.2 \mathrm{~m}^{2} \mathrm{~m}^{-2}\right)$ was observed in the irrigation depth $\mathrm{L}_{4}$ for the dose $\mathrm{K}_{2}$. These results allowed to infer that plants under water deficit showed reduced leaf area and leaf area index, a condition evidenced by plants subjected to the irrigation depth $\mathrm{L}_{1}$. Leaf area is an important factor in the production and determines the use of water by plants and their yield potential is severely inhibited when exposed to water deficit (Fernández et al., 1996). Water stress limits not only the size of individual leaves, but also the number of leaves, because it decreases the number and growth rates of the branches (Taiz et al., 2015).

The regression analysis for the characteristic chlorophyll index $(\mathrm{CI})$ is presented in Figure $3 \mathrm{~B}$. For both $\mathrm{K}_{1}$ and $\mathrm{K}_{2}$ doses, the chlorophyll index decreased always when the water deficit, caused by the application of the lowest irrigation depths, was accentuated. Gonçalves et al. (2010) and Jangpromma et al. (2010) also observed reduction in the chlorophyll index of plants subjected to water stress, in comparison to plants satisfactorily irrigated. The highest value of chlorophyll was observed in the treatment $\mathrm{L}_{4} \mathrm{~K}_{1}$, related to the irrigation depth of $100 \%$ ETc and $\mathrm{K}$ dose equal to $200 \mathrm{~kg} \mathrm{ha}^{-1}$ of $\mathrm{K}_{2} \mathrm{O}$.

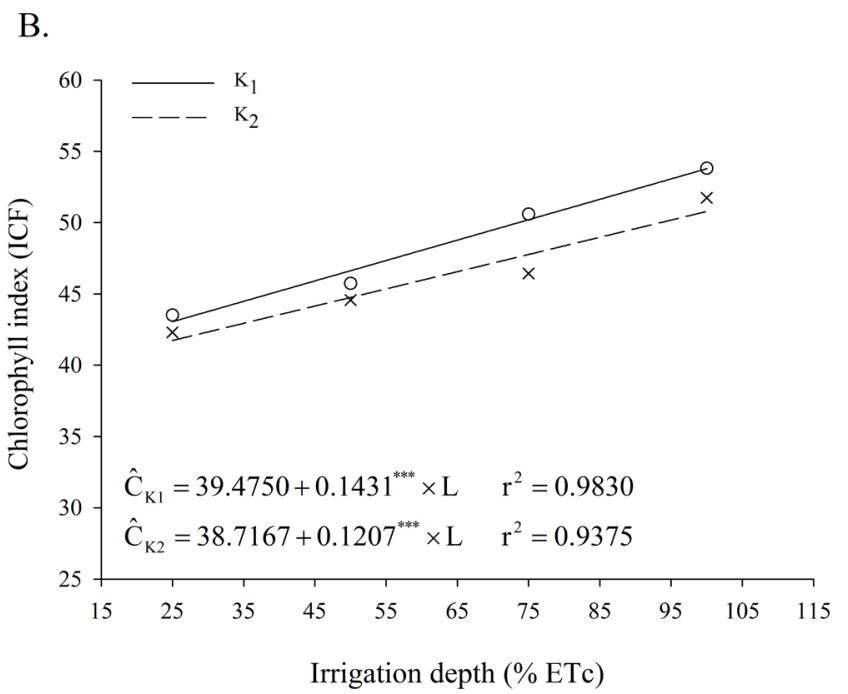

Figure 3. Response of leaf area index (A) and chlorophyll index (B) as a function of the applied irrigation depth (\% ETc) for each potassium dose 
A.

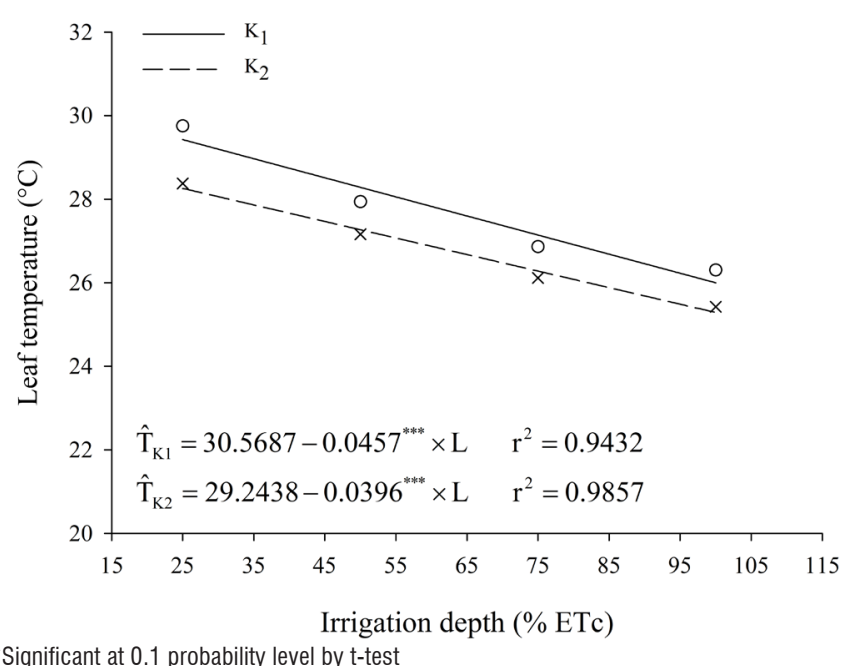

B.

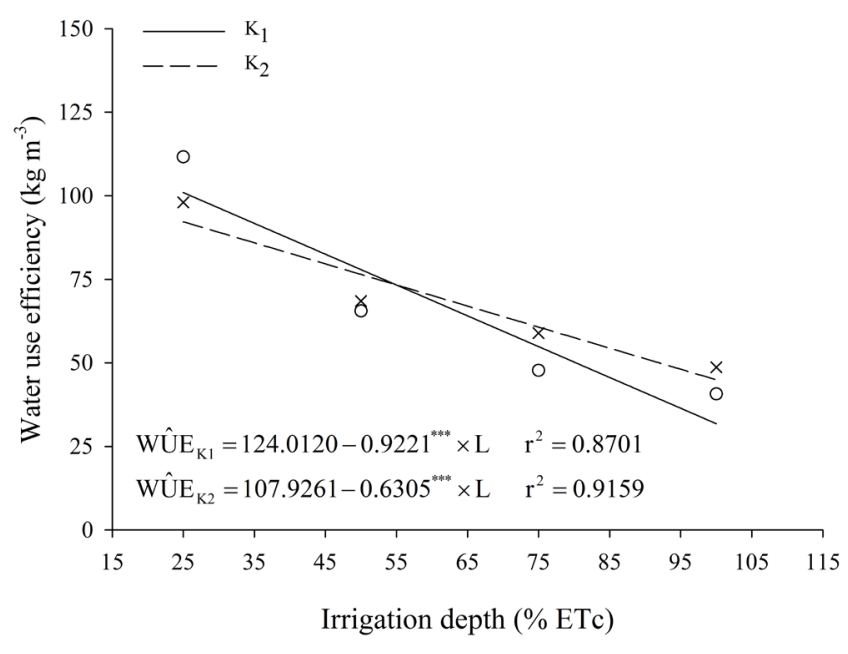

Figure 4. Response of leaf temperature (LT) and water use efficiency (WUE) as a function of the applied irrigation depth (\% ETc) for each potassium dose

It should be pointed out that the application of the dose $\mathrm{K}_{1}$ promoted higher values of $\mathrm{CI}$ in comparison to $\mathrm{K}_{2}$, for all irrigation depths, which can be explained by the fact that the chlorophyll index is dimensionless and proportional to values measured at the laboratory, as $\mathrm{g}$ chlorophyll $\mathrm{g}^{-1}$ leaf or $\mathrm{g}$ chlorophyll area ${ }^{-1}$ of the leaf. Since the dose $\mathrm{K}_{1}$ contributed to lower yield increments (Figure 2A) and leaf area index (Figure $3 \mathrm{~A}$ ), as the irrigation depths increased, compared with the dose $\mathrm{K}_{2}$, the divider of the ratios - $\mathrm{g}$ chlorophyll g-1 leaf or $\mathrm{g}$ chlorophyll area ${ }^{-1}$ of the leaf - used to calculate CI, tends to be smaller, increasing the values of CI.

The responses of the variables leaf temperature and water use efficiency as a function of the irrigation depths for each $\mathrm{K}$ dose are presented in Figure 4.

Based on the results, there was a decrease in temperature with the increase of irrigation depths for both $\mathrm{K}$ doses. The highest temperature was observed in the treatment $\mathrm{L}_{1} \mathrm{~K}_{1}$, related to the irrigation depth of $25 \%$ of ETc and dose of 200 $\mathrm{kg} \mathrm{ha}^{-1}$ of $\mathrm{K}_{2} \mathrm{O}$.

Under water stress, plants exhibit higher leaf temperature, in comparison to those cultivated under full water availability conditions (Testi et al., 2008). Trentin et al. (2011) observed that leaf temperature is closely associated with the process of transpiration. As it increases, there is a reduction in leaf temperature due to the dissipation of energy in the form of latent heat.

Since the lowest $\mathrm{K}$ dose promoted lower plant development, reducing height (Figure 2B) and leaf area index (Figure 3A), compared with the highest dose, there was lower transpiration of the plants in these treatments, increasing leaf temperature, as explained above.

As to the water use efficiency (WUE, Figure 4B), the increase in irrigation depths caused lower water use efficiency at both $\mathrm{K}$ doses, but at the highest irrigation depths - $\mathrm{L}_{3}$ and $\mathrm{L}_{4}$ - the dose $\mathrm{K}_{2}$ was more efficient in the use of water, while at the lowest irrigation depths $\mathrm{L}_{1}$ and $\mathrm{L}_{2}$ - the dose $\mathrm{K}_{1}$ was more efficient.

The decrease in water use efficiency as the irrigation depths increased indicates that the increase in yield was not proportional to the increment in water supply. For the dose $\mathrm{K}_{1}$, the increase of four times in the irrigation depth (25 to $100 \%$ of ETc) promoted only an increment of approximately 1.5 times in the value of yield, while at the dose $\mathrm{K}_{2}$ this increase in the irrigation depth promoted only an increment of approximately two times in the value of yield. The dose $\mathrm{K}_{2}$ led to higher WUE values for the lowest irrigation depths, because there was a greater increment of yield in these treatments with the increase in the applied irrigation depth, compared with the dose $\mathrm{K}_{1}$.

Coelho et al. (2005) claim that water use efficiency can be increased by reducing the applicable irrigation depth (evapotranspiration) in such a way to not drastically reduce yield. According to these authors, this alternative would lead to the maintenance of a high efficiency of the irrigation system, increasing water use efficiency by the reduction in the actual irrigation depth necessary during the stages of growth and development considered not critical for the plants, without significant damage to the expected potential yield.

\section{Conclusions}

1. Maximum values of yield, plant height and leaf area index were obtained with the application of the highest irrigation depth and highest potassium dose.

2. The lowest potassium dose, associated with the lowest irrigation depth, promoted the highest values of leaf temperature and water use efficiency and, when associated with the highest irrigation depth, increased the value of chlorophyll index.

3. Although the highest yield was obtained with the highest irrigation depth and highest potassium dose, it is recommended to cultivate arugula with the lowest irrigation depth and lowest dose, because of the higher water use efficiency for this treatment.

\section{Literature Cited}

Allen, R. G.; Pereira, L. S.; Raes, D.; Smith, J. Evapotranspiration del cultivo: Guias para la determinación de los requerimientos de agua de los cultivos. Roma: FAO, 2006. 298p. 
Angeli, K. P.; Delazari, F. T.; Nick, C.; Ferreira, M. G.; Silva, D. J. $\mathrm{H}$. da. Yield components and water use efficiency in coriander under irrigation and nitrogen fertilization. Revista Brasileira de Engenharia Agrícola e Ambiental, v.20, p.415-420, 2016. https:// doi.org/10.1590/1807-1929/agriambi.v20n5p415-420

Borges, C. T.; Deuner, C.; Rigo, G. A.; Oliveira, S. de; Moraes, D. M. de. O estresse salino afeta a qualidade fisiológica de sementes de rúcula? Enciclopédia Biosfera, v.10, p.1049-1057, 2014.

Carvalho, K. dos S.; Bonfim-Silva, E. M.; Silveira, M. H. D.; Cabral, C. E. A.; Leite, N. Rúcula submetida à adubação nitrogenada via fertirrigação. Enciclopédia Biosfera, v.8, p.1545-1553, 2012.

Cecílio Filho, A. B.; Maia, M. M.; Mendoza-Cortez, J. W.; Rodrigues, M. A.; Nowaki, R. H. D. Épocas de cultivo e parcelamento da adubação nitrogenada para rúcula. Comunicata Scientiae, v.5, p.252-258, 2014.

Chaves Filho, J. T.; Stacciarini-Seraphin, E. Alteração no potencial osmótico e teor de carboidratos solúveis em plantas jovens de lobeira (Solanum lycocarpum St.-Hil.) em resposta ao estresse hídrico. Revista Brasileira de Botânica, v.24, p.199-204, 2001.

Coelho, E. F.; Coelho Filho, M. A.; Oliveira, S. L. Agricultura irrigada: Eficiência de irrigação e de uso de água. Bahia Agrícola, v.7, p.57-60, 2005.

Fernández, C. J.; Mcinnes, K. J.; Cothren, J. T. Water status and leaf area production in water-and nitrogen-stressed cotton. Crop Science, v.36, p.1224-1233, 1996. https://doi.org/10.2135/ cropsci1996.0011183X003600050026x

Gonçalves, E. R.; Ferreira, V. M.; Silva, J. V.; Endres, L.; Barbosa, T. P.; Duarte, W. de G. Trocas gasosas e fluorescência da clorofila a em variedades de cana-de-açúcar submetidas à deficiência hídrica. Revista Brasileira de Engenharia Agrícola e Ambiental, v.14, p.378386, 2010. https://doi.org/10.1590/S1415-43662010000400006

Gonzalez, A. F.; Ayub, R. A.; Reghin, M. Y. Conservação de rúcula minimamente processada produzida em campo aberto e cultivo protegido com agrotêxtil. Horticultura Brasileira, v.24, p.360-360, 2006. https://doi.org/10.1590/S0102-05362006000300018

Jangpromma, N.; Songsri, P.; Thammasirirak, S.; Jaisil, P. Rapid assessment of chlorophyll content in sugarcane using a SPAD chlorophyll meter across different water stress conditions. Asian Journal of Plant Sciences, v.9, p.368-374, 2010. https://doi. org/10.3923/ajps.2010.368.374
Larcher, W. Ecofisiologia vegetal. São Carlos: RiMa, 2006. 531p. Lemos, R.; Santos, R. Manual de descrição e coleta de solo no campo. 5.ed. Viçosa: Sociedade Brasileira de Ciência do Solo, 2005. 100p.

Marenco, R. A.; Lopes, N. F. Fisiologia vegetal: Fotossíntese, respiração, relações hídricas e nutrição mineral. Viçosa: UFV, 2005. 451p.

Osório, J.; Osório, M. L.; Chaves, M. M.; Pereira, J. S. Water deficits are more important in delaying growth than in changing patterns of carbon allocation in Eucalyptus globulus. Tree Physiology, v.18, p.363-373, 1998. https://doi.org/10.1093/treephys/18.6.363

Porto, R. A.; Bonfim-Silva, E. M.; Souza, D. S. M.; Cordova, N. R. M.; Polyzel, A. C.; Silva, T. J. A. Adubação potássica em plantas de rúcula: Produção e eficiência no uso da água. Revista Agro@ mbiente, v.7, p.28-35, 2013.

Ribeiro, A. C.; Guimarães, P. T. G.; Alvarez V., V. H. Recomendação para o uso de corretivos e fertilizantes em Minas Gerais. 5a aproximação. Viçosa: Comissão de Fertilidade do Solo do Estado de Minas Gerais, 1999. 359p.

Silva, V. de P. R. da; Tavares, A. L.; Sousa, I. F. Evapotranspiração e coeficientes de cultivo simples e dual do coentro. Horticultura Brasileira, v.31, p.255-259, 2013. https://doi.org/10.1590/S010205362013000200013

Silveira, M. A. G.; Vitusso, L.; Medina, N. H. Distribuição de potássio em cana-de-açúcar. Brazilian Journal of Radiation Sciences, v.3, p.1-8, 2015. https://doi.org/10.15392/bjrs.v3i1A.138

Taiz, L.; Zeiger, E.; Møller, I. M.; Murphy, A. Plant physiology and development. California: Sinauer Associates Incorporated, 2015. $761 \mathrm{p}$.

Testi, L.; Goldhamer, D. A.; Iniesta, F.; Salinas, M. Crop water stress index is a sensitive water stress indicator in pistachio trees. Irrigation Science, v.26, p.395-405, 2008. https://doi.org/10.1007/ s00271-008-0104-5

Trentin, R.; Zolnier, S.; Ribeiro, A.; Steidle Neto, A. J. Transpiração e temperatura foliar da cana-de-açúcar sob diferentes valores de potencial matricial. Engenharia Agrícola, v.31, p.1085-1095, 2011. https://doi.org/10.1590/S0100-69162011000600006

Viana, E. M.; Kiehl, J. C. Doses de nitrogênio e potássio no crescimento do trigo. Bragantia, v.69, p.975-982, 2010. https://doi.org/10.1590/ S0006-87052010000400024 